\title{
Factors Influencing Customers Acceptance of Using the QR Code Feature in Offline Merchants for Generation Z in Bandung (Extended UTAUT2)
}

\section{Aulia Tiara Imani and Achmad Herlanto Anggono}

Management, School of Business and Management, Institut Teknologi Bandung - Indonesia

\section{Abstract}

Mobile payment services is happening in Indonesia are shifting to support the cashless society future supported by the many tech-savvy consumers in Indonesia. The leading mobile payment players, namely Go-Pay, OVO, DANA, LinkAja, etc. began to expand their target market network by adding the QR Code feature to perform transactions in offline merchants. With the offering transactions of cashbacks, the consumer will more likely to adopt the QR Code because the promotion can only be obtained by making offline transactions at several affiliated merchants. The purpose of this study is

Corresponding Author: Aulia Tiara Imani

tiaraimani24@gmail.com

Received: 7 February 2020

Accepted: 9 March 2020

Published: 23 March 2020

Publishing services provided by Knowledge E

(c) Aulia Tiara Imani and Achmad Herlanto Anggono. This article is distributed under the terms of the Creative Commons

Attribution License, which permits unrestricted use and redistribution provided that the original author and source are credited.

Selection and Peer-review under the responsibility of the ICE-BEES 2019 Conference Committee. to identify the factors that can influence the behavioral intention and the actual usage for using the QR Code feature in mobile payment to perform transactions in offline merchants. This study will also identify the extent to which the actual usage of the QR Code feature can contribute to the National Non-Cash Movement (GNNT), starting from the scope of generation $\mathrm{Z}$ in Bandung. This study will be conducted by using Extended UTAUT2 with nine independent variables of Performance Expectancy (PE), Effort Expectancy (EE), Social Influence (SI), Facilitating Conditions (FC), Hedonic Motivation $(\mathrm{HM})$, Price Value (PV), Habit (HT), Trust (T), and Perceived Risk (PR). These variables will be tested to the Behavioral Intention (BI) and also Actual Use (AU). The result indicates that the Habit is the most significant factors to influence Behavioral Intention. While the others, namely Behavioral Intention, Facilitating Conditions, Hedonic Motivation, and Performance Expectancy influence to Actual Usage and Behavioral Intention.

Keywords: Mobile Payment, QR Code in Offline Merchants, Generation Z, Extended UTAUT2

\section{Introduction}

Digital payment often understands as a consumer who use mobile payment systems to initiate and activate their mobile phone to fulfill the transactions in regards to paying goods and services by using their mobile devices [25]. The completion of the payments and transactions between the buyer and the merchants is considered to be fast and 
straightforward. The payments also can be made anytime and anywhere by holding only a mobile device [30].

Digital payment is also happening in Indonesia, where the shifting of technology to support the cashless society future is also supported by the many tech-savvy consumers in Indonesia [45]. Indonesia's growth regarding digital payment systems is said to be increasingly confident about going all cashless. To that extent, that continuous decline in performing cash transactions occurs to Indonesia of $69 \%$, following the second high in leading the way for cashless payments after Singapore of 76\% [46]. In addition, [4] also added, $44.16 \%$ of users use smartphones/tablets to access the internet, $4.49 \%$ use computers and $39.28 \%$ use both. This shows that the adoption of mobile technology is in trend since Indonesia began introducing mobile payments to the public introduced in 2007, when Telkomsel sent its first digital payment, T-Cash. Then, followed by Dompetku in 2007 and XL Tunai in 2012. Having reached its successful performance in 2017, smartphones recovered to reach their highest point compared to bank accounts, debit cards, e-money accounts, and credit cards [1]

Today, mobile payment in Indonesia are beginning to expand their target market network by adding features for offline transactions. This feature of QR Code payment can be found from the leading mobile payment players, which is, Go-Pay, OVO, T-cash (LinkAja), and DANA. According to [14], Go-Pay is the most popular payment provider by $79 \%$, followed by OVO (58.42\%), T-cash (LinkAja) (55.52\%), and DANA (34.18\%). With the offering transactions of cashbacks, shopping discounts from merchants, and discounts when using the mobile payment, the consumer will more likely to adopt the QR Code because the promotion can only be obtained by making offline transactions at several affiliated merchants [29]. In the meantime, QR Code is known as the payment method that has more key drivers than using other payment method. QR Code allows everyone to perform the transactions by simply scanning the QR Code with their mobile phone [12].

In Indonesia, the adoption of the QR Code is considered as new technology. So, this study approaches the generation who was born to exposed to the changes of technology, namely generation Z in Bandung. Generation Z is the largest populations of human category and also the youngest age range in the world today. Generation Z refer to individuals who were born in the mid-1990s until the mid 2000s [49]. This generation is commonly known as the most highly tech-savvy, easy to swallow online products and has more convenient access to electronic devices, and broad information on the internet $[24,49]$. In addition, according to the survey conducted by [47], generation $Z$ is leading with their usage of mobile payment to perform transactions of $53 \%$ compared to other 
generations. They are more likely to seek mobile payment platforms that seen as the best platform to use. To match this study, based from the website of [5], the population in Bandung area based on the age group from 15-19 is 220,024, age group of 20-24 is 258,830 , and $25-29$ age group is 228,917 . The data indicates that the population of generation $\mathrm{Z}$ in Bandung is much denser than the other age range.

However, not all community has already adapted to the condition where they are most likely not $100 \%$ believe in the concept and mechanism of the digital wallet [42]. In addition, even though there are already many research about the adoption for digital payments, mobile payments, and mobile banking, a study of the use of the QR Code feature on mobile payments in conducting offline merchant transactions has never been done before, especially to evaluate the generation $Z$ in Bandung area. Therefore, this study will focus on looking at the factors that contribute to the behavior to adopt the technology model and customer intention to use the mobile payment by using the Extended UTAUT2 model.

\section{Literature Review}

\subsection{Mobile Payment With QR Code Feature}

Mobile payment defines as a payment system to transferring amounts of cash to pay for products or service with the assistance of portable electronic devices such as tablets or mobile phone $[16,18,23]$. According to [13], mobile payment can be used in offline merchants (physical stores) or online merchants through the mobile phone. There are types of mobile payment features provided, one example is the QR Code feature. QR Code payments are now available to use at purchasing through merchants around the world and regarded as the foundation for the future of cashless payments in the digital age [15]. QR Code provides both consumers and merchants with an affordable and convenient payment service with no compelling reasons to issue physical cards, tokens or Electronic Data Capture (EDC) machines. QR Code also offers more cost-effective payment system to be implemented in F\&B and retail outlets merchants compare to NFC that still requires unique stickers that can be identified by the EDC machine camera [15].

\subsection{Generation Z}

Being adopted from [49], the term Generation Z refers to a group of individuals who were born between the mid-1990s until the mid-2000s. These generations born after 


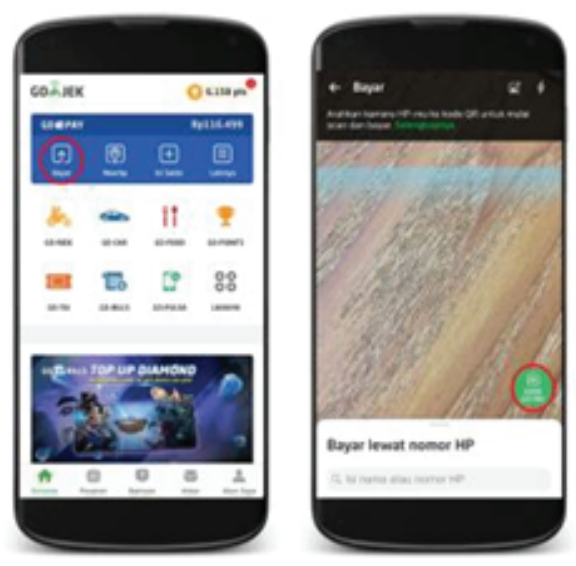

Figure 1: Example of Payment Using QR Code

Generation $Y$ and the grandchildren of the Baby Boomers and raised by Generation $X$ [24]. These generation are known to have common traits and characteristics; one example is that they are commonly dependent on technology [23]. This generation is commonly known as the most highly tech-savvy, easy to swallow online products and has more convenient access to electronic devices, and broad information on the internet $[24,49]$. This happens because Generation $Z$ is the first generation growing up with technology and is known to be more inclined to go fully digital [33].

\subsection{Extended Unified Theory of Acceptance and Use of Technol- ogy 2 (Extended UTAUT2)}

UTAUT is a theory that was proposed by [43] and was later refined to be UTAUT2 by [44]. The objective of UTAUT2 to produce the extensions of the prior theory, UTAUT, to primarily focus more to the consumer use context rather than the organizational context to identify the adoption intentions of an IT/IS. This suggests that UTAUT2 are essential to measuring the validity of UTAUT in consumer context compared to the original one [43].

UTAUT2 is a complex model where [43] has added more constructs compared from the previous UTAUT, which are, Hedonic Motivation (HM), Price Value (PV), and Habit (H) while the prior model already carried four factors which are Performance Expectancy $(\mathrm{PE})$, Effort Expectancy (EE), Social Influence (SI) and Facilitating Conditions (FC). This shows that the UTAUT2 model can be able to explain even more comprehensively to the Behavioral Intention (BI) and the Actual Use (AU) by consumers. However, the model in this study will incorporate from the proposed model from [35] in his prior study as entitled Exploring Mobile Wallet Adoption in Indonesia Using UTAUT2 and [40] in his 
prior study as entitled Extending UTAUT2 To Explore Consumer Adoption Of Mobile Payments. The study stated that the possible extensions of UTAUT2 model that can explain the mobile payment context are Perceived Risk (PR) and Trust (T) and thus affecting the behavioral intention of the usage of mobile payment. Also, this study will examine until the variable of actual use.

\subsubsection{Performance Expectancy towards Behavioral Intention}

Performance expectancy defined as the degree where the individuals believe that using technology will contribute benefits in regards to perform the activities. In the context of mobile payment, individuals perceive that using technology to make payments will enhance their performance in doing such purchasing transactions [43].

$\mathrm{H}_{1}$ : Performance Expectancy (PE) positively influence consumer's behavioral intention (BI) to use QR Code in mobile payment to made transactions in offline merchants

\subsubsection{Effort Expectancy towards Behavioral Intention}

Effort expectancy defined as the degree of ease related to the use of specific technology. In the context of mobile payment, this factor explains where individuals are free from effort and easy to understand the use of certain types of mobile payment [44].

$\mathrm{H}_{2}$ : Effort Expectancy (EE) positively influence consumer's behavioral intention (BI) to use QR Code in mobile payment to made transactions in offline merchants

\subsubsection{Social Influence towards Behavioral Intention}

Social influence defined as the degree which an individual valued the opinions of their significant others such as families, relatives, or friends to use a particular technology. This individual can be influenced by their significant others to use a specific type of mobile payment [43]

$\mathrm{H}_{3}$ : Social Influence (SI) positively influence consumer's behavioral intention (BI) to use QR Code in mobile payment to made transactions in offline merchants 


\subsubsection{Facilitating Conditions towards Behavioral Intention and Actual Use}

Facilitating conditions defined as the degree to which an individual's perception to have adequate resources or access and supporting environment in order to acquire effective adoption of a technology [43]. In consumer use context in UTAUT2, facilitation is seen to be available and spread widely to each consumer and can have a different level of access between each technology available in the market. If an individual has more access to one facilitation, it is more likely to have a higher intention to use one technology. Thus, UTAUT2 decided to link facilitating conditions to both the behavioral intention and the actual use. Facilitating conditions also have a link between the moderating variables such as age, gender and experience [44].

$\mathrm{H}_{4 a}$ : Facilitating Conditions (FC) positively influence consumer's behavioral intention (BI) to use QR Code in mobile payment to made transactions in offline merchants

$\mathrm{H}_{4 b}$ : Facilitating Conditions (FC) positively influence consumer's adoption (AU) to use QR Code in mobile payment to made transactions in offline merchants

\subsubsection{Hedonic Motivation towards Behavioral Intention}

Hedonic Motivation is defined as the feeling of enjoyment, fun, or pleasure when an individual use a technology [44]. The findings from [11] shows that if an individual uses a technology for its own sake, it is more likely to be engaged with the essence of enjoyment and fun. This individual also pays more attention to a novelty in a technology, where the novelty itself contributes to the hedonic motivation effect. In the consumer use context, this factor is found to be important in measuring technology acceptance and actual use.

$\mathrm{H}_{5}$ : Hedonic Motivation (HM) positively influence consumer's behavioral intention (BI) to use QR Code in mobile payment to made transactions in offline merchants

\subsubsection{Price Value towards Behavioral Intention}

Price value explains where the individual sees the technology based on its price and usefulness that further have a significant impact on technology use. In the context of using mobile payment, the price value will be positive if the individual finds that using a particular technology at a specific price, will give them benefits as much as the prices 
applied to its technology. Adding this construct will act as a predictor to behavioral intention in using a technology [44].

$\mathrm{H}_{6}$ : Price Value (PV) positively influence consumer's behavioral intention (BI) to use QR Code in mobile payment to made transactions in offline merchants

\subsubsection{Habit towards Behavioral Intention and Actual Use}

Habit explains where the individual performs a behavior towards technology, and they use it automatically. It is also linked to experience, where experience in the passage of chronological time can form different levels of habit or in another word; the experience can reflect the results of habit. When an individual tends to perform actions towards technology, and they have a specific period, it will produce one individual habit in performing those actions $[32,44]$. Thus, habit links to two variables, which are,

$\mathrm{H}_{7 a}$ : Habit $(\mathrm{HT})$ positively influence consumer's behavioral intention (BI) to use QR Code in mobile payment to made transactions in offline merchants

$\mathrm{H}_{7 b}$ : Habit $(\mathrm{HT})$ positively influence consumer's adoption (AU) to use QR Code in mobile payment to made transactions in offline merchants

\subsubsection{Trust towards Behavioral Intention}

Trust is a subjective belief or an expectation of an individual where other parties will meet the expectation and do not perform opportunistically in a situation, mainly in financial transactions area [19]. In the context of mobile payment, trust is considered to be highly relevant to its context because it involves transactions of money using electronic devices. Other reasons include where mobile payment systems are related to its novelty, tangled environment, and involvement of its mobile network operators [39]. As trust is found to be significant to behavioral intention [40], this study will extend to the model of UTAUT2 and put trust as the variables.

$\mathrm{H}_{8}$ : Trust $(\mathrm{T})$ positively influence consumer's behavioral intention (BI) to use QR Code in mobile payment to made transactions in offline merchants

\subsubsection{Perceived Risk towards Behavioral Intention}

Perceived Risk comes from an individual's feeling of uncertainty towards specific behavior due to the fear of something unexpected and undesirable [40]. In the context of mobile payment, it indicates from the prior study from [27] that the consumer will 
experience the vulnerability to security violations regarding the use of such wireless communications infrastructure. If the perceived risk is high, the individual will more likely choose not to adopt the mobile payment and switch it back to the traditional mode of purchasing transactions [37].

$\mathrm{H}_{9}$ : Perceived Risk (PR) negatively influence consumer's behavioral intention (BI) to use QR Code in mobile payment to made transactions in offline merchants

\subsubsection{Behavioral Intention towards Actual Use}

Behavioral intention is where the individual's behavior affects the actual use behavior of one's technology [43]. Several findings from [3, 26, 44] found that the behavioral intention could significantly affect the actual use behavior of technology. Thus, according to the prior study, this study will formulate the following hypothesis for behavioral intention,

$\mathrm{H}_{10}$ : Behavioral Intention (BI) positively influence consumer's adoption (AU) to use QR Code in mobile payment to made transactions in offline merchants

\subsubsection{Moderating Variables}

In the UTAUT2 model, generated by [44], the method posits three moderating variables, which are, age, gender, and experience that can help the factors to influence the behavioral intention or actual usage behavior. However, this study will not apply any of these moderating variables to see the direct effect of ones variable to another without partially supported or influenced by the moderating variables. In regards to the findings from Yuan \& Kanthawala (2015), found that the moderating variables of gender, age and, experience were not significant to support the variables to influence the behavioral intention to use.

\subsection{Conceptual Framework}

Based on the several works of literature reviewed, this study will propose a conceptual framework drawn below in Figure 2,

\section{Methodology}

This research will use a quantitative method, where the researcher spreads a questionnaire containing the socio-demography variable and also the level of acceptance 


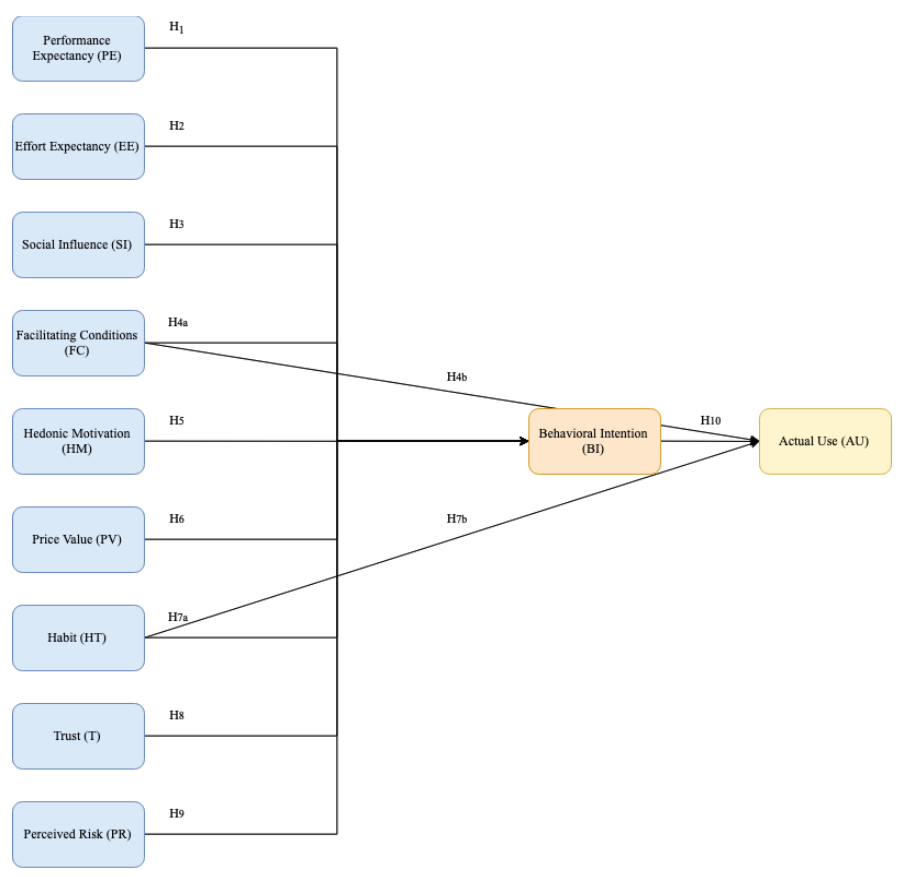

Figure 2: Conceptual Framework

variable with 32 questions. The questionnaires use 7-Point Likert Scale ranging from 1: "Strongly Disagree" and 7: "Strongly Agree" to get the responses along a continuum of possible responses from the participants 34. As for question number 32, for Actual Use variable, the answer will be using 5-point interval scales which are never use, once in three months (rarely), one or two times a month (occasionally), one or two times in 2-3 days (often), many times per day (very often). The collected data will be processed with PLS-SEM method using Smart PLS 3.0. in [48] suggest that the appropriate sample size for using PLS-SEM starts from 100 to 200 . So, the sample size for this study will be 200 respondents.

\section{Discussion}

The data generated from the set of questionnaires were 200 respondents spread around Bandung area with the age group between 17 and 24 years. The respondents have used the QR Code feature that is used to perform transaction on offline merchants. The number of respondents obtained are qualified with the specified minimum sample requirements that covers the generation $\mathrm{Z}$ in Bandung area. 


\subsection{Descriptive Analysis}

The descriptive analysis will cover the explanation of socio-demography of the respondents. It presents in Table 1 below,

TABLE 1: Socio-Demography Information

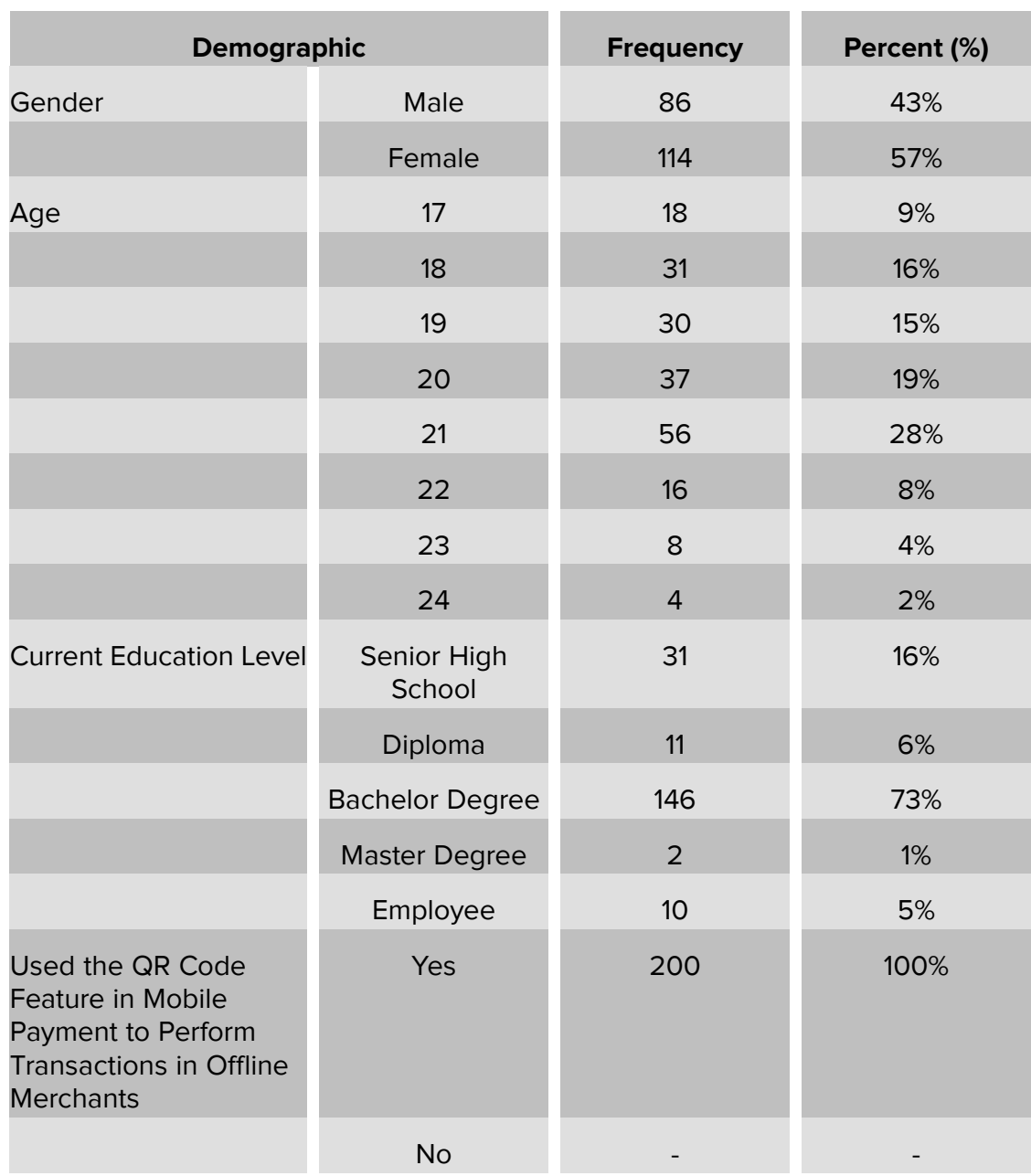

\subsection{Partial Least Square Structural Equation Modelling (PLS-SEM)}

\subsubsection{Descriptive Statistics}

From the table given above, the highest mean can be found in the indicators of EE3 with 6.440 that represents the respondents' understanding of "Easiness in using the technology". The high mean results indicates that most of the respondents do not feel difficult to use Go-Pay with the QR Code feature. While the lowest mean can be found in the indicators of $A U$ with 3.465 that represents the respondents' understanding of 
TABLE 2: Descriptive Statistics

\begin{tabular}{|c|c|c|c|c|c|}
\hline Variables & Indicators & Mean & Std. Deviation & Min & Max \\
\hline \multirow[t]{3}{*}{ PE } & PE1 & 5.880 & 1.066 & 2.000 & 7.000 \\
\hline & PE2 & 5.990 & 1.145 & 2.000 & 7.000 \\
\hline & PE3 & 5.335 & 1.301 & 1.000 & 7.000 \\
\hline \multirow[t]{4}{*}{$\mathrm{EE}$} & EE1 & 6.355 & 0.883 & 4.000 & 7.000 \\
\hline & EE2 & 6.305 & 0.856 & 3.000 & 7.000 \\
\hline & EE3 & 6.440 & 0.766 & 4.000 & 7.000 \\
\hline & EE4 & 6.260 & 0.901 & 3.000 & 7.000 \\
\hline \multirow[t]{3}{*}{ SI } & SI1 & 4.400 & 1.446 & 1.000 & 7.000 \\
\hline & $\mathrm{SI} 2$ & 4.505 & 1.556 & 1.000 & 7.000 \\
\hline & $\mathrm{SI3}$ & 4.495 & 1.449 & 1.000 & 7.000 \\
\hline \multirow[t]{3}{*}{$\mathrm{FC}$} & $\mathrm{FC} 1$ & 5.970 & 1.034 & 1.000 & 7.000 \\
\hline & $\mathrm{FC} 2$ & 6.195 & 0.898 & 2.000 & 7.000 \\
\hline & FC3 & 6.120 & 0.952 & 2.000 & 7.000 \\
\hline \multirow[t]{3}{*}{$\mathrm{HM}$} & HM1 & 5.835 & 1.135 & 2.000 & 7.000 \\
\hline & HM2 & 5.885 & 1.163 & 1.000 & 7.000 \\
\hline & HM3 & 5.400 & 1.360 & 1.000 & 7.000 \\
\hline \multirow[t]{3}{*}{ PV } & PV1 & 6.145 & 1.065 & 1.000 & 7.000 \\
\hline & PV2 & 5.900 & 1.015 & 2.000 & 7.000 \\
\hline & PV3 & 5.870 & 0.966 & 2.000 & 7.000 \\
\hline \multirow[t]{3}{*}{ HT } & HT1 & 4.695 & 1.487 & 1.000 & 7.000 \\
\hline & $\mathrm{HT} 2$ & 3.635 & 1.809 & 1.000 & 7.000 \\
\hline & HT3 & 3.720 & 1.764 & 1.000 & 7.000 \\
\hline \multirow[t]{3}{*}{$\mathrm{T}$} & $\mathrm{T} 1$ & 5.915 & 0.999 & 2.000 & 7.000 \\
\hline & T2 & 5.780 & 1.092 & 1.000 & 7.000 \\
\hline & T3 & 5.765 & 1.053 & 2.000 & 7.000 \\
\hline \multirow[t]{3}{*}{ PR } & PR1 & 3.770 & 1.660 & 1.000 & 7.000 \\
\hline & PR2 & 3.645 & 1.624 & 1.000 & 7.000 \\
\hline & PR3 & 3.705 & 1.720 & 1.000 & 7.000 \\
\hline \multirow[t]{3}{*}{$\mathrm{BI}$} & BI1 & 5.490 & 1.058 & 2.000 & 7.000 \\
\hline & $\mathrm{BI} 2$ & 5.140 & 1.233 & 1.000 & 7.000 \\
\hline & $\mathrm{BI3}$ & 5.070 & 1.373 & 1.000 & 7.000 \\
\hline$A U$ & $\mathrm{AU}$ & 3.465 & 0.565 & 3.000 & 5.000 \\
\hline
\end{tabular}

"Usage frequency in using the technology". The low mean results indicates that the frequency in using the QR Code feature in mobile payment is still in low adoption. 
The maximum and minimum values in Table 2 above show the highest and lowest values that respondents choose from each question indicator. From the table, the highest value for the variables PE, EE, SI, FC, HM, PV, HT, T and PR is 7, where the value of 7 is the highest value of the 7-point Likert Scale in the questionnaire set. Then, the highest value for the $A U$ variable is 5 , where the value of 5 is also the highest value of the 5-point Interval Scale in the questionnaire set. While the minimum value in each indicators show to be different from each indicators.

\subsubsection{Outer Model (Measurement Model)}

\section{Indicator Reliability}

Indicator reliability can be measured by seeing the outer loadings for each indicators. The minimum value of the indicator reliability should be 0.70 or higher [48] to be acceptable, or between 0.40 to 0.70 are said to be adequate [22]. The results of the indicator reliability can be obtained through performing the PLS Algorithm in Smart PLS 3.0 by looking at the "Outer Loadings" of the model. Based on the result shown in Table 3 , all of the indicators are reliable because it has fulfilled the minimum value of indicator reliability.

\section{Internal Consistency Reliability}

The internal consistency reliability were conducted to evaluate the constructs measures are reliable or not [20]. To determine the reliability, Cronbach's alpha and composite reliability were both considered because the Cronbach's alpha represent the lower bound of the reliability and the composite reliability represent the upper bound of the reliability. The requirement for composite reliability values should be 0.70 or higher, but 0.6 or higher for exploratory research to be acceptable [6]. From Table 4, the result shows that all of the variables has exceed the minimum value of 0.70 . It means that each constructs has high level of internal consistency reliability and said to be adequate to be assessed further.

\section{Convergent Validity}

To measure the convergent validity, it needs to be underlined that the common rule of thumb is the constructs to have minimum value of outer loadings of 0.708 . Based 
TABLE 3: Indicator Reliability

\begin{tabular}{|c|c|c|c|c|}
\hline Variables & Indicator & Outer Loadings & $\begin{array}{l}\text { Indicator } \\
\text { Reliability }\end{array}$ & Conclusion \\
\hline \multirow[t]{3}{*}{ PE } & PE1 & 0.859 & 0.737881 & Reliable \\
\hline & PE2 & 0.791 & 0.625681 & Reliable \\
\hline & PE3 & 0.855 & 0.731025 & Reliable \\
\hline \multirow[t]{4}{*}{ EE } & EE1 & 0.876 & 0.767376 & Reliable \\
\hline & EE2 & 0.865 & 0.748225 & Reliable \\
\hline & EE3 & 0.907 & 0.822649 & Reliable \\
\hline & EE4 & 0.858 & 0.736164 & Reliable \\
\hline \multirow[t]{3}{*}{$\mathrm{SI}$} & $\mathrm{SI} 1$ & 0.871 & 0.758641 & Reliable \\
\hline & $\mathrm{S} 12$ & 0.891 & 0.793881 & Reliable \\
\hline & $\mathrm{SI3}$ & 0.918 & 0.842724 & Reliable \\
\hline \multirow[t]{3}{*}{ FC } & $\mathrm{FC1}$ & 0.858 & 0.736164 & Reliable \\
\hline & $\mathrm{FC} 2$ & 0.883 & 0.779689 & Reliable \\
\hline & FC3 & 0.869 & 0.755161 & Reliable \\
\hline \multirow[t]{3}{*}{$\mathrm{HM}$} & HM1 & 0.922 & 0.850084 & Reliable \\
\hline & $\mathrm{HM} 2$ & 0.918 & 0.842724 & Reliable \\
\hline & HM3 & 0.890 & 0.7921 & Reliable \\
\hline \multirow[t]{3}{*}{ PV } & PV1 & 0.869 & 0.755161 & Reliable \\
\hline & PV2 & 0.842 & 0.708964 & Reliable \\
\hline & PV3 & 0.883 & 0.779689 & Reliable \\
\hline \multirow[t]{3}{*}{ HT } & $\mathrm{HT} 1$ & 0.873 & 0.762129 & Reliable \\
\hline & HT2 & 0.933 & 0.870489 & Reliable \\
\hline & HT3 & 0.909 & 0.826281 & Reliable \\
\hline \multirow[t]{3}{*}{$\mathrm{T}$} & $\mathrm{T} 1$ & 0.890 & 0.7921 & Reliable \\
\hline & $\mathrm{T} 2$ & 0.906 & 0.820836 & Reliable \\
\hline & T3 & 0.875 & 0.765625 & Reliable \\
\hline \multirow[t]{3}{*}{ PR } & PR1 & 0.869 & 0.755161 & Reliable \\
\hline & PR2 & 0.863 & 0.744769 & Reliable \\
\hline & PR3 & 0.867 & 0.751689 & Reliable \\
\hline \multirow[t]{3}{*}{$\mathrm{BI}$} & BI1 & 0.892 & 0.795664 & Reliable \\
\hline & $\mathrm{B} 12$ & 0.916 & 0.839056 & Reliable \\
\hline & $\mathrm{BI} 3$ & 0.928 & 0.861184 & Reliable \\
\hline$A U$ & $A U$ & 1.000 & 2.000 & Reliable \\
\hline
\end{tabular}

on Table 5, all of the variables has already acquired the requirement. Further, the convergent validity is measured by seeing the Average Variance Extracted (AVE) to 
TABLE 4: Internal Consistency Reliability

\begin{tabular}{|l|c|c|l|}
\hline Variable & $\begin{array}{c}\text { Cronbach's Alpha } \\
(\alpha)\end{array}$ & $\begin{array}{c}\text { Composite } \\
\text { Reliability (CR) }\end{array}$ & Conclusion \\
\hline PE & 0.784 & 0.874 & Reliable \\
\hline EE & 0.899 & 0.930 & Reliable \\
\hline FC & 0.876 & 0.924 & Reliable \\
\hline SI & 0.840 & 0.903 & Reliable \\
\hline HM & 0.896 & 0.935 & Reliable \\
\hline PV & 0.833 & 0.899 & Reliable \\
\hline HT & 0.890 & 0.932 & Reliable \\
\hline T & 0.869 & 0.920 & Reliable \\
\hline PR & 0.834 & 0.900 & Reliable \\
\hline BI & 0.899 & 0.937 & Reliable \\
\hline AU & 1.000 & 1.000 & Reliable \\
\hline
\end{tabular}

the extent of how much the construct can explain more than half of the variance of its indicators. According to [6], the minimum AVE value should 0.50 or above. The result shows that all of the variables are above 0.50, as stated below in Table 5 ,

TABLE 5: Convergent Validity

\begin{tabular}{l|c|c|} 
Variables & $\begin{array}{c}\text { Average Variance } \\
\text { Extracted (AVE) }\end{array}$ & Conclusion \\
\hline PE & 0.698 & Valid \\
\hline EE & 0.769 & Valid \\
\hline FC & 0.802 & Valid \\
\hline SI & 0.757 & Valid \\
\hline HM & 0.828 & Valid \\
\hline PV & 0.748 & Valid \\
\hline HT & 0.820 & Valid \\
\hline T & 0.793 & Valid \\
\hline PR & 0.750 & Valid \\
\hline BI & 0.832 & Valid \\
\hline AU & 1.000 & Valid \\
\hline
\end{tabular}

\section{Discriminant Validity}

Discriminant validity explains the extent to which a construct can be completely different from other constructs. By identifying discriminant validity, it can be ascertained whether 
a construct can explain something different that is not represented by another construct in a model. The method used for assess the discriminant validity is by using the FornellLarcker criterion [17] and the cross-loading factors. As seen from both Table 6 and Table 7, all of the square root of AVE are greater than the correlation among all latent variables. Also, the outer loadings of each indicators are greater than any of its cross-loadings on other constructs. Thus, it can be concluded that all of the variables has passed the discriminant validity test.

TABLE 6: Discriminant Validity - Fornell-Larcker Criterion

\begin{tabular}{|c|c|c|c|c|c|c|c|c|c|c|c|}
\hline & PE & EE & SI & FC & HM & PV & HT & $\mathbf{T}$ & PR & BI & $\mathbf{A U}$ \\
\hline PE & 0.836 & & & & & & & & & & \\
\hline EE & 0.529 & 0.877 & & & & & & & & & \\
\hline SI & 0.387 & 0.168 & 0.896 & & & & & & & & \\
\hline FC & 0.460 & 0.568 & 0.147 & 0.870 & & & & & & & \\
\hline HM & 0.584 & 0.414 & 0.378 & 0.409 & 0.910 & & & & & & \\
\hline PV & 0.440 & 0.359 & 0.275 & 0.310 & 0.410 & 0.865 & & & & & \\
\hline HT & 0.458 & 0.177 & 0.551 & 0.198 & 0.379 & 0.249 & 0.905 & & & & \\
\hline $\mathbf{T}$ & 0.409 & 0.481 & 0.318 & 0.379 & 0.520 & 0.511 & 0.341 & 0.890 & & & \\
\hline PR & 0.166 & -0.009 & 0.294 & 0.059 & 0.175 & 0.028 & 0.398 & 0.034 & 0.866 & & \\
\hline BI & 0.602 & 0.404 & 0.471 & 0.438 & 0.571 & 0.428 & 0.685 & 0.526 & 0.208 & 0.912 & \\
\hline$A U$ & 0.238 & 0.187 & 0.172 & 0.152 & 0.165 & 0.211 & 0.223 & 0.235 & -0.016 & 0.324 & 1.000 \\
\hline
\end{tabular}

\subsubsection{Inner Model (Structural Model)}

To test the hypotheses that were built before in the conceptual framework, the research will evaluate the model quality such as the path coefficients, path significant ( $p$-value or t-statistics) and coefficient of determination (R2). The t-value of path significance should be larger than 1.96 for it to be significantly affect the endogenous variable. To determine the $\mathrm{R} 2$, the acceptable value are $0.75,0.50$ and 0.25 described as substantial, moderate and weak, respectively.

From Table 8, it presents that there are five variables that show a significant value to its dependent variables because the t-statistics has exceed the minimum value of 1.96. These variables are mentioned from the most significant to the least significant, which are $\mathrm{HT} B \mathrm{BI}, \mathrm{BI} \mathrm{AU}, \mathrm{FC} B \mathrm{BI}, \mathrm{HM} \mathrm{BI}$, and PE BI, respectively. Habit shows to have the highest path coefficient $(\beta)$ as an independent variable towards Behavioral Intention with the value of 0.479 . It means that every increase in Habit in 1 point will increase behavioral intention by 0.479 . The value of 0.479 also shows that the variable of Habit 
TABLE 7: Discriminant Validity - Cross Loadings

\begin{tabular}{|c|c|c|c|c|c|c|c|c|c|c|c|}
\hline & PE & EE & SI & FC & HM & PV & HT & $\mathbf{T}$ & PR & BI & $A U$ \\
\hline 1 & 859 & 492 & 0,251 & 134 & 96 & 35 & 0,363 & 0 , & 0,064 & 527 & ,168 \\
\hline$=2$ & 791 & 484 & ,280 & ,384 & 475 & 0,378 & 0,288 & 0,343 & ,138 & 0,454 & 0,201 \\
\hline E3 & 0.855 & 0,357 & 0,436 & 0,337 & 0,494 & 0,343 & 0,486 & 0,319 & 0,215 & 0,523 & 0,230 \\
\hline EE1 & 0,464 & 0.876 & 0,137 & 0,513 & 0,353 & 0,305 & 0,152 & 0,421 & 0,010 & 0,372 & 0.180 \\
\hline EE2 & 0,479 & 0.865 & 0,120 & 0,478 & 0,304 & 0,263 & 0,206 & 0,363 & 0,028 & 0,329 & 0.183 \\
\hline EE3 & 0,450 & 0.907 & 0,181 & 0,458 & 0,401 & 349 & 0,109 & 0,454 & $-0,057$ &, 363 & .186 \\
\hline EE4 & 0,462 & 0.858 & 0,149 & 0,542 & 0,391 & 0,336 & 0,158 & 0,446 & $-0,012$ & 0,350 & 0.106 \\
\hline SI1 & 0,362 & 0,186 & 0.871 & 0,098 & 0,291 & 0,282 & 0,444 & 0,319 & 0,195 & 0,420 & 0,140 \\
\hline$S 12$ & 0,306 & 0,119 & 0.897 & 0,125 & 0,339 & 0,213 & 0,506 & 0,271 & 0,309 & 0,396 & 0,137 \\
\hline 513 & 0,368 & 0,145 & 0.918 & 0,169 & 0,384 &, 243 & 0,529 & ,265 & ,288 &, 446 & ,183 \\
\hline FC1 & 0,363 & 0,419 & 11 & 0.858 & 0,286 & 0,230 & 152 & 0,274 & 0,028 & ,362 & D,144 \\
\hline FC2 & 0,425 & 0,606 & 0,106 & 883 & 350 & 0,291 & 0,169 & 0,376 & 0,057 & ,350 & ,147 \\
\hline FC3 & 0,411 & 0,464 & 0,161 & 0.869 & 0,423 & 0,286 & 0,194 & 0,338 & 0,067 & 0,426 & 0,110 \\
\hline HM1 & 0,535 & 0,385 & 0,317 & 0,387 & 0.922 & 0,368 & 0,322 & 0,450 & 0,135 & 0,493 & 0,135 \\
\hline HM2 & 0,581 & 0,467 & 0,346 & 0,419 & 0.918 & 0,395 & 0,349 & 0,522 & 0,094 & 0,535 & 0,173 \\
\hline HM3 & 0,478 & 278 & 367 & ,312 & 890 & 355 & 362 & 14 & 0,248 & 527 & ,142 \\
\hline गV1 & 308 & 230 & 228 & 196 & 249 & 869 & 4 & 394 & ,023 & 333 & ,137 \\
\hline गV2 & 0,382 & 0,259 & 292 & 229 & 317 & 842 & 0,248 & 0,393 & 0,028 & ,337 & ,203 \\
\hline PV3 & 0,437 & 0,414 & 0,205 & 0.356 & 0,467 & 0.883 & 0,247 & 0,520 & 0,021 & 0,428 & 0,203 \\
\hline HT1 & 0,464 & 0,263 & 0,444 & 0,242 & 0,357 & 0,239 & 0.873 & 0,320 & 0,306 & 0,686 & 0,258 \\
\hline HT2 & 0,381 & 0,084 & 0,518 & 125 & 0,308 & 0,220 & 0.933 & 0,277 & 0,391 & 0,572 & 0,176 \\
\hline HT3 & 0,383 & 0,108 & 0,540 & 0,156 & 0,358 & 0,213 & 0.909 & 0,324 & 0,394 & 580 & 0,156 \\
\hline T1 & 0,374 & 0,448 & 0,231 & 319 & 0,448 & 0,425 & 0,264 & 0.890 & 0,008 & 0,436 & 0.194 \\
\hline T2 & 0,328 & 0,443 & 0,317 & 0,349 & 0,513 & 0,518 & 0,312 & 0.906 & 0,023 & 0,492 & 0.215 \\
\hline T3 & 0,392 & 0,396 & 0,296 & 0,342 & 0,425 & 0,417 & 0,331 & 0.875 & 0,059 & 0,473 & 0.217 \\
\hline PR1 & 0,121 & $-0,030$ & 0,259 & 0,022 & 0,140 & 0,021 & 0,390 & 0,022 & 0.869 & 0,185 & $-0,067$ \\
\hline PR2 & 0 , & 0,034 & 0,241 & 0,082 & 0,169 & $-0,013$ & 357 & 0,028 & 0.863 & 0,191 & 0,033 \\
\hline PR3 & 0,145 & $-0,033$ & 0,267 & 0,046 & 0,144 & 0,071 & 0,280 & 0,040 & 0.867 & 0,161 & $-0,008$ \\
\hline BI1 & 0,533 & 0,397 & 0,378 & 0,451 & 0,537 & 0,368 & 0,556 & 0,513 & 0,136 & 0.892 & 0.288 \\
\hline $\mathrm{B} 12$ & 0,524 & 0,351 & 0,430 & 0,381 & 0,484 & 0,410 & 0,625 & 0,500 & 0,165 & 0.916 & 0.352 \\
\hline BI3 & 0,587 & 0,359 & 0,476 & 0,370 & 0,540 & 0,393 & 0,688 & 0,429 & 0,263 & 0.928 & 0.248 \\
\hline$A U$ & 0 & 0.187 & 0.172 & 52 & 0.165 & 211 & 23 & 35 & -0.016 & 0.324 & 1.000 \\
\hline
\end{tabular}

has positive effect to behavioral intention. The second highest path coefficient $(\beta)$ is Behavioral Intention towards Actual Use with the value of 0.317. It means that every increase in Behavioral Intention in 1 point will increase actual use by 0.317 . The value of 
TABLE 8: Inner Model (Structural Model)

Structural Path
Performance Expectancy
Behavioral Intention
Effort Expectancy Behavioral
Intention
Social Influence Behavioral
Intention
Facilitating Conditions
Behavioral Intention
Facilitating Conditions Actual
Use
Hedonic Motivation
Behavioral Intention
Price Value Behavioral
Intention
Habit Behavioral Intention
Habit Actual Use
Trust Behavioral Intention
Perceived Risk Behavioral
Intention
Behavioral Intention Actual
Use

\begin{tabular}{c}
$\begin{array}{c}\text { Path Coefficients } \\
(\beta)\end{array}$ \\
0.139 \\
\hline 0.013 \\
\hline 0.031 \\
\hline 0.141 \\
\hline 0.013 \\
\hline 0.149 \\
\hline 0.067 \\
\hline 0.479 \\
\hline 0.003 \\
\hline 0.127 \\
\hline-0.057 \\
\hline 0.317 \\
\hline
\end{tabular}

\begin{tabular}{c} 
T-Statistics \\
\hline 2.055 \\
\hline 0.217 \\
\hline 0.491 \\
\hline 2.613 \\
\hline 0.191 \\
\hline 2.490 \\
\hline 1.020 \\
\hline 8.246 \\
\hline 0.032 \\
\hline 1.770 \\
\hline 1.403 \\
\hline 3.292 \\
\hline
\end{tabular}

\begin{tabular}{|l|}
\hline P Values \\
\hline 0.040 \\
\hline 0.829 \\
\hline 0.624 \\
\hline 0.009 \\
\hline 0.849 \\
\hline 0.013 \\
\hline 0.308 \\
\hline 0.000 \\
\hline 0.975 \\
\hline 0.077 \\
\hline 0.161 \\
\hline 0.001 \\
\hline
\end{tabular}

0.317 also shows that the variable of Behavioral Intention has positive effect to actual use. Facilitating Conditions has a path coefficient $(\beta)$ towards Behavioral Intention of 0.141. It means that every increase in Facilitating Conditions in 1 point will increase the behavioral intention by 0.141 . The value of 0.141 also shows that the variable of Facilitating Conditions has positive effect to actual use. Hedonic Motivation has a path coefficient $(\beta)$ towards Behavioral Intention of 0.149 . It means that every increase in Hedonic Motivation in 1 point will increase the behavioral intention by 0.149 . The value of 0.149 also shows that the variable of Hedonic Motivation has positive effect on behavioral intention. Performance Expectancy has a path coefficient $(\beta)$ towards behavioral intention of 0.139. It means that every increase in Performance Expectancy in 1 point will increase the behavioral intention by 0.139 . The value of 0.139 also shows that the variable of Performance Expectancy has positive effect on behavioral intention.

However, the remaining variables of Effort Expectancy, Social Influence, Facilitating Conditions, Price Value, Trust, and Perceived Risk towards behavioral intention has found to be not significant towards Behavioral Intention. Also, the variables of Habit 
also found to be insignificant towards Actual Use. These all happen because the tstatistics is below 1.96 . So, the path coefficients $(\beta)$ in these variables are not applicable to represent the sample of QR Code users in Bandung.

Besides path coefficient $(\beta)$, the $\mathrm{R}^{2}$ value was also calculated to explain the variance of each endogenous variables. $R^{2}$ value shows how much variance can be explained by exogenous variables (independent variables) to endogenous variables to endogenous variables (dependent variables). The minimum standards for the measurement, according to [48], are $0.75,0.50$ and 0.25 described as substantial, moderate and weak, respectively. Below are present the results of the $R^{2}$ square from the model testing in Table 4.8,

TABLE 9: $R^{2}$ Square

Variables
Behavioral Intention (BI)
Actual Use (AU)

R2 Square

0.662

0.106

The result of the procedure shows that the $\mathrm{R}^{2}$ square of Behavioral Intention (BI) is 0.662 or $66.2 \%$ and considered as moderate. It means that the amount of $66.2 \%$ is the ability of the independent variable (PE, EE, FC, SI, HM, PV, HT, T, and PR) to explain the dependent variable moderately. For the variable of Actual Use (AU), the R2 square shows the amount of 0.106 or $10.6 \%$ and considered as weak. It means that the amount of $12 \%$ is the ability of the independent variable (FC, $\mathrm{HT}$, and $\mathrm{BI}$ ) to explain the dependent variable weakly.

\subsection{Hypothesis Testing}

The results of this study indicate that Performance Expectancy has an effect where the more users feel that using the QR Code feature in mobile payments is useful and increases their productivity, the more users have the intention to adopt the feature in their daily life. Users also feel that by adopting the technology, they get benefits by doing the transaction. This findings is consistent with the prior study conducted by [36] about mobile payment adoption, [2] about mobile banking adoption, [26] about online banking adoption, and [3] about internet banking adoption.

Effort Expectancy is explained as the degree where users find it easy to use $Q R$ Code technology. In this finding, Effort Expectancy was found to be insignificant in this research towards behavioral intention to adopt the QR Code feature, which is contrary to prior findings, namely [35], [36], [2], and [3]. However, this finding is supported by [9] 
TABLE 10: Hypothesis Testing

\begin{tabular}{|c|c|c|c|c|c|}
\hline \multirow[t]{2}{*}{ Hypotheses } & \multirow{2}{*}{$\begin{array}{c}\text { Structural } \\
\text { Path }\end{array}$} & \multirow{2}{*}{$\begin{array}{c}\text { Path } \\
\text { Coefficients } \\
(\beta)\end{array}$} & \multirow[t]{2}{*}{ T-Statistics } & \multicolumn{2}{|c|}{ Information } \\
\hline & & & & Results & Conclusion \\
\hline $\mathrm{H}_{1}$ & PE BI & 0.139 & 2.055 & $\begin{array}{l}\text { Positively } \\
\text { Significant }\end{array}$ & Accepted \\
\hline $\mathrm{H}_{2}$ & $\mathrm{EE} \mathrm{BI}$ & 0.013 & 0.217 & $\begin{array}{c}\text { Not } \\
\text { Significant }\end{array}$ & Rejected \\
\hline $\mathrm{H}_{3}$ & $\mathrm{SI} \mathrm{BI}$ & 0.031 & 0.491 & $\begin{array}{c}\text { Not } \\
\text { Significant }\end{array}$ & Rejected \\
\hline $\mathrm{H}_{4 a}$ & $\mathrm{FC} \mathrm{BI}$ & 0.141 & 2.613 & $\begin{array}{l}\text { Positively } \\
\text { Significant }\end{array}$ & Accepted \\
\hline $\mathrm{H}_{4 b}$ & FC AU & 0.013 & 0.191 & $\begin{array}{c}\text { Not } \\
\text { Significant }\end{array}$ & Rejected \\
\hline $\mathrm{H}_{5}$ & $\mathrm{HM} \mathrm{BI}$ & 0.149 & 2.490 & $\begin{array}{l}\text { Positively } \\
\text { Significant }\end{array}$ & Accepted \\
\hline $\mathrm{H}_{6}$ & PV BI & 0.067 & 1.020 & $\begin{array}{c}\text { Not } \\
\text { Significant }\end{array}$ & Rejected \\
\hline $\mathrm{H}_{7 a}$ & $\mathrm{HT} \mathrm{BI}$ & 0.479 & 8.246 & $\begin{array}{l}\text { Positively } \\
\text { Significant }\end{array}$ & Accepted \\
\hline $\mathrm{H}_{7 b}$ & HT AU & 0.003 & 0.032 & $\begin{array}{c}\text { Not } \\
\text { Significant }\end{array}$ & Rejected \\
\hline $\mathrm{H}_{8}$ & $\mathrm{~T} \mathrm{BI}$ & 0.127 & 1.770 & $\begin{array}{c}\text { Not } \\
\text { Significant }\end{array}$ & Rejected \\
\hline $\mathrm{H}_{9}$ & PR BI & -0.057 & 1.403 & $\begin{array}{c}\text { Not } \\
\text { Significant }\end{array}$ & Rejected \\
\hline $\mathrm{H}_{10}$ & $\mathrm{BI} \mathrm{AU}$ & 0.317 & 3.292 & $\begin{array}{l}\text { Positively } \\
\text { Significant }\end{array}$ & Accepted \\
\hline
\end{tabular}

where it stated that the high level of mobile phone usage making the user too familiar with the rapid development of a technology. Although this finding shows insignificance relationship, the user feels that using the QR Code feature for mobile payment is easy to use, easy to learn, clear and understandable and easy to be mastered. This may occur when viewed from the respondents of this research, which is generation $Z$ with the age range 17-24, that generation $Z$ are commonly dependent on technology. They were born when technology was growing rapidly making them known as tech-savvy. They already feel familiar with the use of existing technologies. Thus, the level of difficulty to use the technology, namely Effort Expectancy, is not a consideration for the behavioral intention to use the QR Code feature in mobile payment.

The results of this study indicate that Social Influence does not make the users have the intention to adopt the QR Code feature in mobile payment. This even might happen because the user does not value opinions from the people closest to them to 
use technology. The users feel that they could still have the intention to use QR Code without their significant others being really use the technology. This finding is in line from [2] about the adoption of mobile banking, where their environment seems less interested in recommending a technology to others.

The results of this research indicate that Facilitating Conditions can draw users to have the intention to adopt the technology. Users feel that they can easily have the access to knowledge to use the QR Code feature. Users also feel that the QR Code feature is compatible with their devices, making it easy for them to use it. Even though the access to resources to use the QR Code feature on mobile payment is not too high, compared to the other two factors above, it does not mean that the users do not acquire the intention to adopt the QR Code feature in mobile payment. This finding is in line with the prior study conducted by [26].

Facilitating Conditions to the actual adoption to use the QR Code features has found to be not significant. This might be happen because the Facilitating Conditions can only affect to actual use indirectly through behavioral intention and not directly to the actual usage. These users may still possessed the resources and knowledges needed, but it does not enough to make them to actually use the QR Code feature in mobile payment. This finding is in line with [9].

Hedonic Motivation is described as an encouragement in the form of enjoyment, fun, and feeling entertained when individuals use the technology. In this study, Hedonic Motivation affect the intention of users to use the QR Code feature in mobile payment. Users may feel that with the use of the QR Code feature in mobile payment, they get a novelty feeling due to performing their activities with the technology. This finding is in line with the prior study from [50] and [35]. The findings stated that the users intention is also triggered not only from the utilitarian motivation or its functionality, but also they pay attention to the user experience they get in performing the technology.

Price Value explains that when individuals using the QR Code in mobile payment at a specific price, it will give them benefits as much as the prices applied to its technology. The results from this study indicates that the Price Value do not affect the users' intention to adopt the QR Code feature in mobile payment. The users may feel that the technology give them a reasonable price, valuableness of the money spent and valuableness of the technology itself. On the contrary, the advantages given from using the mobile payment application, such as, cashbacks or promotions do not necessarily affect their interest to adopt the behavioral intention of the QR Code payment. This might be happen because the users may feel that the cashbacks or promotions are not something they really need. Also, this is in contrast with this finding where the users tend to use the technology for 
their enjoyment and personal satisfaction. This is in line with the prior study from [35] and [36].

Habit is the extent to which the users use the QR Code feature gradually which then turns into a habit. In this study, habit is the most significant variable to influence the behavioral intention. This finding may occurred because the users of this study are generation Z, where they are known to be accustomed to being exposed to mobile payments and other technologies, making it their habit to use these technologies. This finding is consistent with the prior study conducted by [35] and [26] that also stated that habit was significantly influenced the behavioral intention to use the application.

In this study, habit has found to be not significant to the actual adoption to the use of QR Code feature. This can happen because Habit can only affect to actual use indirectly through behavioral intention and not directly to the actual usage. This is in line with the understanding of habit, where habit can be developed from the activities that performed gradually and produce a habit. However, the questionnaire also shows that the users have not really made the use of the QR Code feature in mobile payment as their habit. This might happen because the adoption of cashless users in Indonesia are still in the inception stage, where this stage shows how low the adoption of users to become cashless [41]. Moreover, the use of a mobile payment with a QR Code was actually implemented in 2018, when the industry of mobile payment application began to emerge and offered cashback or promotion to the public. This finding is not in line with the prior study conducted by [3] that stated otherwise.

In this study, Trust has found to be not significant to the behavioral intention to use the QR Code feature. Trust is explained where other parties will not behave opportunistically towards other individuals. It turns out that the trustworthiness of the technology, the commitments that the application offered and the application commitment to keep the customers' interest in using the technology do not necessarily affect the intention to adopt. This might happen because the users are exposed to multiple choices of other mobile payment system. Also, the users may not feel to have the urgency to trust one's particular technology because the users pay attention to novelty of technology. This study is in line with the prior research by [31] conducted in Indonesia that stated Trust do not significant to the behavioural intention.

In this study, Perceived Risk has found to be not significant to behavioral intention to adopt the technology. Perceived Risk is explained as the users' feeling of uncertainty towards something unexpected and undesirable. This finding shows that the users do not feel risky or have doubts about using the technology. This finding is in contrary with the prior study from [38] and [3]. 
Behavioral Intention is described as the users' intention and preferences to continue to use the QR Code feature. The results of this study indicate that the users are more likely to continue to use the technology in the future, have the willingness to use it in daily usage and to use it frequently. Although their intention is considered as high, but their frequency in actual use is still relatively average. Most of them use it occasionally or often. This finding is in line with [3] and [26] that also stated that behavioral intention affects actual use.

\section{Conclusion and Recommendation}

Based on the discussion presented in the previous chapter, the researcher has identified the factors that can influence the adoption of the QR Code feature in mobile payment to perform transactions in offline merchants. The findings shows that five out of twelve hypotheses proposed in this study are found to be accepted in regards to the usage the QR Code features in offline merchants. The accepted hypotheses are from the most significant, which are, $\mathrm{HT} \mathrm{BI}, \mathrm{BI} \mathrm{AU}, \mathrm{FC} \mathrm{BI}, \mathrm{HM} \mathrm{BI}$, and $\mathrm{PE} \mathrm{BI}$, respectively. All of these hypotheses are accepted because it fulfills the minimum requirement of t-statistics of more than 1.96 and has positive value of path coefficients, which is known as significant. The significant' variables represent the population of the object in this study, which is Generation Z in Bandung that already used the QR Code. However, the remaining seven hypotheses are rejected because the t-statistics are less than 1.96 which is not significant. The rejected hypotheses can only represent the respondents of this study, but not the population in this study.

This research adopted the theoretical foundations from [40], which is the new produced conceptual framework of Extended UTAUT2 that affect to behavioral intention and actual usage. This research has found out that seven out of twelve hypotheses were not significant to the behavioral intention and actual usage of the QR Code feature. Thus, a modified conceptual framework is provided as the result from this research as seen in Figure 3 ,

The modified conceptual framework can be used further as the reference or literature for those who want to do a research in regards the use of QR Code feature in offline merchants among Generation Z in Bandung.

Seeing that users greatly value their habit to use the QR Code feature, generation $Z$ already understands that using technology that often changes is common to them. However, to increase their use of a technology, it is highly recommended for the industry QR Code from mobile-based payment to monitor current user interface provided for this 


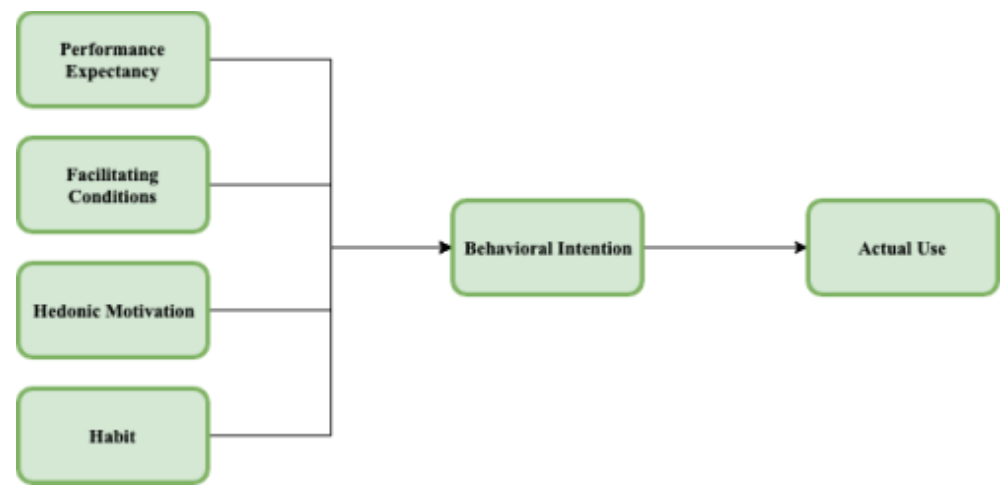

Figure 3: Modified Conceptual Framework

generation. Even though generation $\mathrm{Z}$ is adapt to fast-changing environment, but it also needs to be underlined to use the originality of it. This is due to the fact that this adoption accounts for until the Transitioning stage, considered as not so preferable stage, and also to reach more inclusive users that can understand the easiness and the basic of the user interface provided. Also, the researcher suggest the industry to reach even more inclusive merchants, not only in the F\&B area, but also in the fashion industry, miscellaneous industry, goods and services industry, etc.. The users will be exposed to the QR Code payment gradually, making them interested to pay with this method.

The researcher also suggest to provide the access of facilitations to a more inclusive audience. The industry can consider making a special user interface for people with disabilities and also promoting knowledge of how to use it to the target market. In addition, access can be added to the users who are still under the age of 17 with age restrictions/parental guidance. Users who are still under the age of 17 , can still get full access for all the features, but still under parents' consent so their financial can still be maintained. This is due to the limitations of generation $Z$ that can use this feature. The researcher suggest the industry to provide it so all of the generation $Z$ from 1995 to 2010 born can experience the use of the feature.

More programs and features should be added as the feeling of the experience is necessary in this research. The company should take a look into the target market of the users. Because, the users tend to see the application from their experiences (userbased experiences). This issue can be done by adding new programs in the application frequently. Also, other programs can also be added and implemented based on the user's important days, such as birthdays or marriage days. This can increase the sense of engagement in novelty, where this generation really pay their attention in this factors to use the application. 
In regards to the user's productivity, the researcher suggest the industry to improve their system to increase the efficiency and effectivity. One example to implement is that the industry should work with more conventional banks. This action is done so that the balance in the application can be integrated with the bank. By doing this, the user does not need to go back and forth to open two applications just to make a top-up on the mobile application. This will increase their productivity, where they will not feel difficult and become accustomed to using the QR Code in mobile payment.

Since the variance that explains the Actual Use is considered as weak, future research can extend the variables or segmentations to further increasing significant value of the variance. So, this study can explain more than behavioral intention, but in an actual use contextual to actually see the usage of the QR Code frequently in daily life.

\section{References}

[1] Agusta, J. \& Hutabarat, K., 2018. Mobile Payments in Indonesia: Race To Big Data Domination, s.I.: Metra Digital Innovation (MDI);Mandiri Sekuritas.

[2] Alalwan, A. A., Dwivedi, Y. K. \& Rana, N. P., 2017. Factors influencing adoption of mobile banking by Jordanian bank customers: Extending UTAUT2 with trust. International Journal of Information Management, pp. 99-110.

[3] Alalwan, A. A., Dwivedi, Y. K., Rana, N. P. \& Algharabat, R., 2018. Examining factors influencing Jordanian customers' intentions and adoption of internet banking: Extending UTAUT2 with risk. Journal of Retailing and Consumer Services, pp. 125138.

[4] Asosiasi Penyelenggara Jasa Internet Indonesia, 2017. Penetrasi \& Perilaku Pengguna Internet Indonesia 2017, s.l.: Teknopreneur.

[5] Badan Pusat Statistik Provinsi Jawa Barat, 2017. Proyeksi Penduduk Menurut Kelompok Umur dan Jenis Kelamin di Kota Bandung, 2017. [Online] Available at: https://bandungkota.bps.go.id/statictable/2019/01/04/179/proyeksi-pendudukmenurut-kelompok-umur-dan-jenis-kelamin-di-kota-bandung-2017.html [Accessed 26 March 2019].

[6] Bagozzi, R. P. \& Yi, Y., 1988. On the Evaluation of Structural Equation Models. Journal of the Academy of Marketing Science, 16(1), pp. 74-94.

[7] Bank Indonesia, 2014. Elektronifikasi dan Keuangan Inklusif. [Online] Available at: https://www.bi.go.id/id/edukasi-perlindungan-konsumen/edukasi/produkdan-jasa-sp/elektronifikasi-dan-ki/Pages/default.aspx[Accessed 26 March 2019]. 
[8] Bank Indonesia, 2014. Press Releases - Bank Indonesia Launches National NonCash Movement. [Online] Available at: https://www.bi.go.id/en/ruang-media/siaranpers/Pages/sp_165814.aspx[Accessed 26 March 2019].

[9] Baptista, G. \& Oliveira, T., 2015. Understanding mobile banking: The unified theory of acceptance and use of technology combined with cultural moderators. Computers in Human Behavior, Volume 50, pp. 418-430.

[10] Bayero, M. A., 2015. Effect of Cashless Economy Policy on financial inclusion in Nigeria: An exploratory study. Procedia - Social and Behavioral Sciences, Volume 172, pp. 49-56.

[11] Brown, S. A. \& Venkatesh, V., 2005. Model of Adoption of Technology in Households: A Baseline Model Test and Extension Incorporating Household Life Cycle. MIS Quarterly, pp. 399-426.

[12] Business Insider US, 2018. One photo shows that China is already in a cashless future. [Online] Available at: https://www.businessinsider.sg/alipay-wechat-paychina-mobile-payments-street-vendors-musicians-2018-5/?r=US\&IR=T[Accessed 26 March 2019].

[13] Crowe, M., Rysman, M. \& Stavin, J., 2010. Mobile Payments in the United States at Retail Point of Sale: Current Market and Future Prospects, s.I.: s.n.

[14] DailySocial, 2018. Fintech Report 2018, s.l.: Otoritas Jasa Keuangan; JAKPAT.

[15] Deloitte, 2018. Bolstering financial inclusion in Indonesia, s.I.: PT Deloitte Consulting.

[16] Dewan, S. G. \& Chen, L.-d., 2005. Mobile Payment Adoption in the US: A Crossindustry, Crossplatform Solution. Journal of Information Privacy and Security, 1(2), pp. 4-28.

[17] Fornell, C. \& Larcker, D. F., 1981. Evaluating Structural Equation Models with Unobservable Variables and Measurement Error. Journal of Marketing Research, 18(1), pp. 39-50.

[18] Francisco Liébana-Cabanillas, I. R. d. L. \& Montoro-Ríos, F., 2017. Intention to use new mobile payment systems: a comparative analysis of SMS and NFC payments. Economic Research-Ekonomska Istraživanja, 30(1), pp. 892-910.

[19] Gefen, D., Karahanna, E. \& Straub, D. W., 2003. Trust and TAM in Online Shopping: An Integrated Model. MIS Quarterly, pp. 51-90.

[20] Hair, J. F., Black, W. C., Babin, B. J. \& Anderson, R. E., 2014. Multivariate Data Analysis. s.I.:Pearson Education Limited.

[21] Hair, J. F., Hult, G. T. M., Ringle, C. M. \& Sarstedt, M., 2017. A PRIMER ON PARTIAL LEAST SQUARES STRUCTURAL EQUATION MODELING (PLS-SEM). 2nd ed. s.I.SAGE Publications, Inc.. 
[22] Hulland, J., 1999. Use of Partial Least Squares (PLS) in Strategic Management Research: A Review of Four Recent Studies. Strategic Management Journal, 20(2), pp. $195-204$.

[23] Investopedia, 2018. Mobile Payment. [Online] Available at: https://www.investopedia. com/terms/m/mobile-payment.asp[Accessed 1 April 2019].

[24] Jain, V., Vatsa, R. \& Jagani, K., 2014. Exploring Generation Z's Purchase Behavior towards Luxury Apparel: a Conceptual Framework. Romanian Journal of Marketing, Issue 2, pp. 18-29.

[25] Tkos, S. \& Fokus, F., 2004. Mobile Payment: A Journey Through Existing Procedures and Standardization Initiatives. IEEE Communications Surveys \& Tutorials, 6(4), pp. 44-66.

[26] Khan, I. U., Hameed, Z. \& Khan, S. U., 2017. Understanding Online Banking Adoption in a Developing Country: UTAUT2 with Cultural Moderators. Journal of Global Information Management, pp. 43-65.

[27] Kim, G., Shin, B. \& Lee, H. G., 2009. Understanding dynamics between initial trust and usage intentions of mobile banking. Info Systems J, pp. 283-311.

[28] KPMG Siddharta Advisory, 2017. Retail payments in Indonesia, s.I.: KPMG Indonesia.

[29] KumparanTECH, 2018. Go-Pay Beri Promo Pay Day di 2.000 Restoran dan Toko, Ada Cashback 50\%. [Online] Available at: https://kumparan.com/@kumparantech/ go-pay-beri-promo-pay-day-di-2-000-restoran-dan-toko-ada-cashback-501543229299384995023 [Accessed 26 March 2019].

[30] Liébana-Cabanillas, F., Sánchez-Fernández, J. \& Muñoz-Leiva, F., 2014. Antecedents of the adoption of the new mobile payment systems: The moderating effect of age. Computers in Human Behavior, Issue 35, pp. 464-478.

[31] Limantara, N., Jingga, F. \& Surja, S., 2018. Factors Infuencing Mobile Payment Adoption in Indonesia. International Conference on Information Management and Technology (ICIMTech), pp. 373-377.

[32] Limayem, M., Hirt, S. G. \& Cheung, C. M. K., 2007. How Habit Limits the Predictive Power of Intention: The Case of Information Systems Continuance. MIS Quarterly, pp. 705-737.

[33] Linnes, C. \& Metcalf, B., 2017. iGeneration And Their Acceptance of Technology. pp. 11-26.

[34] 5

[35] Megadewandanu, S., Suyoto \& Pranowo, 2016. Exploring Mobile Wallet Adoption in Indonesia Using UTAUT2: An Approach from Consumer Perspective. International Conference on Science and Technology-Computer (ICST). 
[36] Oliveira, T., Thomas, M., Baptista, G. \& Campos, F., 2016. Mobile payment: Understanding the determinants of customer adoption and intention to recommend technology. Computers in Human Behavior, pp. 404-414.

[37] Pathirana, P. A. \& Azam, S. F., 2017. Factors Influencing the Use of Mobile Payments - A Conceptual Model. National Information Technology Conference.

[38] Riquelme, H. E. \& Rios, R. E., 2010. The moderating effect of gender in the adoption of mobile banking. International Journal of Bank Marketing, pp. 328-341.

[39] Slade, E. L., Williams, M. D. \& Dwivedi, Y. K., 2014. Devising a research model to examine adoption of mobile payments: An extension of UTAUT2. The Marketing Review, pp. 311-336.

[40] Slade, E., Williams, M. \& Dwivdei, Y., 2013. Extending UTAUT2 To Explore Consumer Adoption of Mobile Payments. UK Academy for Information Systems Conference Proceedings.

[41] Thomas, H., Jain, A. \& Angus, M., 2013. Measuring progress toward a cashless society, s.l.: MasterCard Advisors.

[42] Tirto, 2017. Evolusi Gojek Sebagai Fintech Lewat Go-Pay. [Online] Available at: https://tirto.id/evolusi-gojek-sebagai-fintech-lewat-go-pay-cAvw [Accessed 26 March 2019].

[43] Venkatesh, V., Morris, M. G., Davis, G. B. \& Davis, F. D., 2003. User Acceptance of Information Technology: Toward a Unified View. MIS Quarterly, 27(3), pp. 425-478.

[44] Venkatesh, V., Thong, J. Y. L. \& Xu, X., 2012. Consumer Acceptance and Use of Information Technology: Extending The UNified Theory of Acceptance and Use of Technology. MIS Quarterly, 36(1), pp. 157-178.

[45] Visa, 2017. Rise Of The Digitally Engaged Consumer, Southeast Asia: Visa.

[46] Visa, 2019. The Road Ahead Consumer Payment Trends in Southeast Asia, Southeast Asia: Visa.

[47] Vision Critical, 2016. The Everything Guide to Generation Z, s.l.: s.n.

[48] Wong, K. K.-K., 2013. Partial Least Squares Structural Equation Modeling (PLS-SEM) Techniques Using SmartPLS. Marketing Bulletin, Volume 24, pp. 1-32.

[49] Wood, S., 2013. Generation Z as Consumers: Trends and Innovation. Institute for Emerging Issues.

[50] Yang, S., 2013. Understanding Undergraduate Students' Adoption of Mobile Learning Model: A Perspective of the Extended UTAUT2. Journal of Convergence Information Technology (JCIT), pp. 969-979. 
[51] Yuan, S. \& Kanthawala, S., 2015. Keep Using My Health Apps: Discover Users' Perception of Health and Fitness Apps with the UTAUT2 Model. Telemedicine and e-Health, pp. 735-741. 